\title{
Turystyka a obszary chronione w perspektywie międzynarodowych konwencji ochrony środowiska
}

\author{
Agata Kosieradzka-Federczyk \\ Wydział Filozofii Chrześcijańskiej, Uniwersytet Kardynała Stefana Wyszyńskiego \\ ul. Wóycickiego 1/3, 01-938 Warszawa \\ a.federczyk@uksw.edu.pl
}

\begin{abstract}
Streszczenie
Artykuł prezentuje wybrane zagadnienia dotyczące ruchu turystycznego na obszarach podlegających ochronie ze względu na wartości przyrodnicze. Problematyka została zaprezetnowana w świetle wybranych dokumentów międzynarodowego prawa ochrony środowiska. Przywołane (jedynie w części dokumenty) pokazują duże zainteresowanie ze strony prawa międzynarodowego, wyrażające się w podejmowaniu problematyki na spotkaniach, przygotowywaniu przewodników, poradników mających za zadanie uświadomienie jak ważne dla prawidłowej ochrony obszarów jest prawidłowe zarządzanie ruchem turystycznym. Odpowiedzią na zidentyfikowane problemy jest zrównoważona turystyka.
\end{abstract}

\section{Słowa kluczowe}

turystyka, międzynarodowa ochrona środowiska, zrównoważona turystyka

\section{Zagadnienia wprowadzające}

Turystyka w kontekście obszarów chronionych stanowi od dawna przedmiot zainteresowania podmiotów aktywnych na forum międzynarodowym, jak również przedstawicieli doktryny. Efekty działalności pierwszej stanowią liczne akty prawne właściwe prawu międzynarodowemu, bezpośrednio (rzadko) lub pośrednio (zdecydowanie częściej) odnoszące się do kwestii turystyki. Natomiast zainteresowanie doktryny wyraża się w bardzo licznych publikacjach prezentujących relacje między turystyką a ochroną przyrody.

Wśród przyczyn zainteresowania dotyczącego oddziaływania turystyki wskazuje się znaczący wzrost liczby turystów. Szacuje się, że turystyka stanowi jeden z najszybciej rosnących sektorów światowej gospodarki (May 1999: 57), szacuje się że stanowi 5.5\% światowego PKB (Perez-Salom 2001: 803), co bezpośrednio przekłada się na liczbę osób odwiedzających obszary cenne przyrodniczo.

Oblicze turystyki zmieniało się wraz z rozwojem społecznym, prowadząc do powstania profesjonalnych przedsiębiorców zajmujących się organizowaniem wyjazdów i pobytu turystów. Wśród niedawnych zmian - w kontekście tematu artykułu - na uwagę zasługuje gałąź przemysłu turystycznego specjalizująca się w organizowaniu wycieczek do miejsc egzotycznych, gdzie podstawową atrakcją jest przede wszystkim dzika przyroda, czyste środowisko, 
wyjątkowe krajobrazy, szczególne wartości przyrodnicze.

Ruch turystyczny w obszarach chronionych może wywołać skutki mające różny charakter. Już sama obecność ludzi może prowadzić do wyrządzenia szkód. Przykładem może być sytuacja goryli (Gorilla gorilla beringei) żyjących w dwóch odizolowanych populacjach w Virunga Volcanoes na granicy Rwandy, Zairu i Ugandy i w lasach Ugandy. Obszary Virungas są chronione w ramach parku narodowego zlokalizowanego na obszarach tych trzech krajów. Kontakt z ludźmi - turystami zaciekawionymi tym rzadkim i nielicznym gatunkiem, doprowadził do przeniesienia choroby związanej z oddychaniem z ludzi na goryli, która spowodowała śmiertelność w tym gatunku porównywalną do tej wyrządzonej przez wojnę domową w Rwandzie (m.in. A. Gillespie 2007: 186- 187).

Nie można zapominać o efektach pozytywnych, które powstają w różnych wymiarach: to osobiste korzyści (przeżycia) - turyści mają możliwość zobaczenia, zrozumienia i docenienia wartości, dla których obszary obejmowane są ochroną (chodzi o obszary chronione w celu zachowania biofizycznych procesów, określonych warunków, takich jak populacja dziko występujących roślin i zwierząt, warunków naturalnych, krajobrazu, dziedzictwa kulturowego, jak również lokalnych warunków życia itp.), to emocje wywołane odpoczynkiem, poznaniem nowych obszarów, często wolnych od antropopresji. W aspekcie ekonomicznym ruch turystyczny może przyczynić się do rozwoju gospodarczego lokalnej społeczności i kraju oraz może, co istotne, stanowić źródło finansowania dla obszarów podlegających ochronie.

To, że turystyka ma, oprócz oblicza pozytywnego również oblicze negatywne, jest oczywiste. Nie chodzi to o szukanie jednych i drugich (licznie opisanych m.in. w doktrynie) przykładów i ważenie ich skutków w celu poszukiwania, która strona przeważa, lecz - w oparciu o stan współistnienia obu zjawisk - przedstawienia wysiłków podejmowanych na rzecz takiego zarządzania obszarami chronionymi i dziko występującymi gatunkami fauny i flory, aby obszary mogły prawidłowo wypełniać funkcje ochronne dla których zostały utworzone, a dziko występujące gatunki nie były narażone na wyginięcie.

W celu pogodzenia rosnącego ruchu turystycznego w miejscach cennych przyrodniczo z dostępnością tych miejsc, wprowadzono pojęcie „zrównoważonej turystyki”, oznaczające taką turystykę, która nie prowadzi do negatywnego oddziaływania turystów na miejsca przez nich odwiedzane.

Te i inne relacje (opisane w dalszej części artykułu) stanowiły katalizator dla działań podejmowanych na forum międzynarodowym, mających zwrócić uwagę na konieczność zarządzania turystyką na terenach podlegających ochronie. Celem artykułu jest przybliżenie podejmowanych działań w podziale na wybrane trzy zagadnienia. Pierwsze, to przegląd działań w ramach wybranych międzynarodowych konwencji ochrony środowiska dotyczących obszarów podlegającymi ochronie, mających niejako charakter uniwersalny. Drugie zagadnienie dotyczy regulacji ruchu turystycznego na obszarze Antarktyki. Wybór uzasadniają dwa czynniki - niewątpliwie jest to obszar o szczególnym statusie (również prawnym) na Ziemi, ponadto regulacje dotyczące turystyki są jednymi z najbardziej rozwiniętych. Natomiast trzecie zagadnienie dotyczy ochrony dzikich zwierząt i roślin w związku $\mathrm{z}$ turystyką $\mathrm{w}$ ramach konwencji o międzynarodowym handlu dzikimi zwierzętami i roślinami gatunków zagrożonych wyginięciem (CITES).

\section{Turystyka a obszary podlegające ochronie}

Zagadnienie turystyki na obszarach podlegających ochronie było obecne podczas Szczytu nt. zrównoważonego rozwoju odbytego w 2002 r. w Johannesburgu, na którym wyrażono poparcie dla prac prowadzonych w ramach Konwencji o różnorodności 
biologicznej dotyczących zrównoważonego wykorzystania zasobów biologicznych w aspekcie turystyki (Plan Implementacji Szczytu Ziemi nt. zrównoważonego rozwoju, 2002: par. 44 b).

Podczas Piątego Światowego Kongresu Parków w 2003 r. podkreślono rolę jaką odgrywa turystyka, często stanowiąc wsparcie dla zachowania terenów chronionych. Dotyczy to wzrostu wsparcia finansowego, co przekłada się na rozwój gospodarczy oraz ograniczanie ubóstwa. Podkreślono konieczność promowania właściwego zachowania wśród turystów, jak również monitorowania, a gdzie to konieczne, zmniejszania negatywnego oddziaływania powstałego w wyniku turystyki. Uczestnicy Kongresu wezwali do zrozumienia relacji łączących trzy zjawiska: turystykę, ochronę obszarów oraz lokalny rozwój. Ponadto zauważyli konieczność odpowiednich szkoleń dotyczących oddziaływania turystyki dla osób zajmujących się ochroną obszarów (Rekomendacja 5.12).

Kolejny istotny dokument dotyczący zrównoważonej turystyki na obszarach podlegających ochronie stanowi wynik współpracy pomiędzy UNEP, Światową Organizacją Turystyki oraz Międzynarodową Unią Ochrony Przyrody. W jej ramach został przygotowany $\mathrm{w} 2002 \mathrm{r}$. dokument $\mathrm{w}$ formie przewodnika dotyczącego planowania i zarządzania równoważoną turystyką na terenach objętych ochroną (Eagles et al. 2002). W oparciu o zebrane i przedstawione dotychczasowe doświadczenia dotyczące zarządzania obszarami podlegającymi ochronie, zwrócono uwagę na konieczność zarządzania turystyką oraz na fakt, że jej negatywne skutki - dzięki odpowiedniemu zarządzaniu - mogą zostać odwrócone.

Klamrą spinającą opisane działania były prace podjęte w ramach Spotkania Stron Konwencji o różnorodności biologicznej. Doprowadziły one do przyjęcia Przewodnika nt. bioróżnorodności i rozwoju turystyki, dotyczącego zarządzania turystyką w sposób ekologiczny, ekonomiczny oraz zrównoważony społecznie (dalej jako Przewodnik). Jego adresatami są podmioty publiczne różnych szczebli władz lokalnych i centralnych zarządzające terenami chronionymi ze względu na bioróżnorodność.

W Przewodniku położono nacisk na podejście do turystyki oparte o zarządzanie. Wymaga ono rozpoznania problematyki, określenia wizji oraz celów, uwarunkowań prawnych, przeprowadzenia oceny oddziaływania, opracowania środków minimalizujących negatywny wpływ. Dopiero po tym etapie powinno nastąpić przyjęcie strategii dotyczącej turystyki. Istotny element stanowi monitorowanie i raportowanie dotyczące wdrażania strategii, co pozwala na podejmowanie działań stanowiących odpowiedź na ciągle zmieniające się procesy zachodzące w ekosystemie. Elastyczne zarządzanie pozwala na podjęcie działań w odpowiedzi na występujące nowe problemy oraz „uczenie się w działaniu” (pkt 74 Wytycznych).

Włączenie w proces przygotowania strategii ocen oddziaływania, a przez to również lokalnej społeczności, czyni z całego postępowania instrument partycypacyjny. Lokalna społeczność jest $\mathrm{w}$ największym stopniu odbiorcą skutków wywołanych przez ruch turystyczny - zarówno pozytywnych, jak i negatywnych.

Chociaż Przewodnik miał status niewiążący, Strony Konwencji skierowały zaproszenie do podmiotów oddziałujących międzynarodowo - Światowej Organizacji Turystyki, UN on Trade and Development oraz UNDP, Banku Światowego, WTO, oraz banków regionalnych do jego stosowania w bieżącej pracy i finansowaniu projektów z nim związanych.

Podejście dotyczące kontroli ruchu turystycznego zostało przejęte do konwencji międzynarodowych oraz regionalnych, takich jak Konwencja helsińska - rekomendacja Helcom 21/3 Przewodnik dla zrównoważonej i przyjaznej środowisku turystyce na wybrzeżach Morza Bałtyckiego.

Regulacje dotyczące turystyki zostały przyjęte również w ramach Konwencji o ochronie wędrownych gatunków dzikich zwierząt sporządzonej w Bonn 23 czerwca 
1979 r., w szczególności w dodatkowych umowach, takich jak:

- Afrykańsko-euroazjatyckie porozumienia dotyczące ochrony wędrownych ptaków wodnych otwarte do podpisu w 1996 r., obejmuje ok 254 gatunków ptaków - AEWA Conservation Guidelines no. 7 Wytyczne o rozwoju ekoturystyki na obszarach wodno-błotnych przyjęte w $2002 \mathrm{r}$. i zmieniane w kolejnych latach;

- porozumienie o ochronie albatrosów oraz petreli z 2001 r. - ACAP Action Plan przyjęty w 2004 r. w Australii, w którym stwierdzono konieczność kontroli zbliżania się turystów do karmiących ptaków;

- memorandum dotyczące przyjęcia środków ochronnych dla kulika cienkodziobego, z 1994 r.

- porozumienie w sprawie ochrony waleni w Morzu Czarnym i Śródziemnomorskim oraz przyległych obszarów Atlantyku z 1996 r. (Porozumienie ACCOBAMS). W rezolucji 4.7 Wytyczne dotyczące komercyjnego oglądania waleni w rejonie objętym Porozumieniem ACCOBAMS przyjętej na czwartym spotkaniu stron w $2010 \mathrm{r}$. zalecono objęcie komercyjnych pokazów zezwoleniami poprzedzonymi m.in. oceną oddziaływania. Jeżeli ocena będzie wskazywała na wystąpienie zagrożenia w postaci znaczących negatywnych skutków dotyczących dobrostanu waleni, zezwolenie nie powinno zostać wydane.

W ramach Konwencji o obszarach wodno-błotnych mających znaczenie międzynarodowe, zwłaszcza jako środowisko życiowe ptactwa wodnego sporządzonej w Ramsar 2 lutego 1971 r., strony indywidualnie reagują na zagrożenia wynikające z ruchu turystycznego $\mathrm{w}$ formie rekomendacji. Takie podejście zastosowano w sprawie Dollart - obszar naturalnych wód słonawych Morza Północnego (na terenie Holandii oraz Niemiec), będący cenny przyrodniczo ze względu m.in. na siedliska ptaków. Wydano zalecenia, aby ograniczać ruch turystyczny, a niektóre tereny wyłączyć w ogóle dostępności dla turystów, zakazać całorocznych polowań (Rekomendacja nr 9 Ochrona Dollart).

Pomimo istniejących różnic dotyczących treści poszczególnych wytycznych, można wskazać cechę wspólną, jaką stanowi promowanie zrównoważonej turystyki, która prowadzi do ochrony przyrody.

Wśród definicji przyjętych w różnych aktach międzynarodowych, na uwagę zasługuje stanowisko Rady Europy, zdaniem której zrównoważona turystyka oznacza każdą formę aktywności turystycznej, która: szanuje środowisko; zapewnia w długim okresie zachowanie naturalnych oraz kulturowych zasobów; jest społecznie i gospodarczo akceptowalna i sprawiedliwa (Rada Europy 1995).

Przedsiębiorcy działający w obszarze turystyki powinni mieć strategie dotyczące środowiska, co wiąże się z posiadaniem kadry wykwalifikowanej w tym zakresie, usługi turystyczne powinny charakteryzować się wysokimi standardami środowiskowymi, konieczny jest rozwój kulturalny i ekonomiczny społeczeństw wrażliwych, ochrona środowiska ma pierwszeństwo przed finansową opłacalnością w zarządzaniu, zarówno w publicznym jak i prywatnym sektorze.

\section{Turystyka na obszarze Antarktyki}

Komercyjna turystyka w obszarze Antarktyki rozpoczęła się w końcu lat 50-tych ubiegłego wieku. Obszar Antarktyki to szczególny obszar pod względem przyrodniczym, co niewątpliwie stanowiło o dużej atrakcyjności dla turystów, a w konsekwencji przyczyniło się do znacznego rozwoju przemysłu turystycznego, specjalizującego się w wycieczkach statkiem w obszar Antarktyki. Ruch turystyczny obecnie odbywa się głównie na statkach średniej wielkości, a wyjątek pod tym względem stanowi, pływający od 2007 r. Golden Princess mogący zabrać 3700 pasażerów (Wright 2008: 45).

Ze względu na intensywność ruchu turystycznego, został on zakwalifikowany jako zagrożenie dla obszaru. Chodzi zarówno 
o obecność osób, wycieczkowców, jak również o skutki katastrof, takich jak rozbicie samolotu Air New Zealand 901 w 1971 r., czy zatonięcie statku Mr Explorer w 2007 r.

W zakresie ruchu turystycznego można wyróżnić trzy zasadnicze źródła regulacji. Pierwszy stanowią regulacje prawa międzynarodowego dedykowane Antarktyce, tworzące system, w których podstawowym dokumentem jest Układ w sprawie Antarktyki z 1959 r.; drugi to pozostałe ogólne regulacje prawa międzynarodowego, w szczególności prawa międzynarodowego ochrony środowiska; trzeci dotyczy prawa państwa bandery statku.

Z jednej strony dwa pierwsze źródła regulacji pozwalają wprowadzać wspólne dla państw ograniczenia, które nie byłyby zapewne możliwe, gdyby ochrona Antarktyki była regulowana wyłącznie poprzez prawodawstwa krajowe. Z drugiej strony prawu temu brakuje takiej skuteczności, jaką charakteryzuje sprawnie działający krajowy system prawny.

Zawarty w 1959 r. Układ w sprawie Antarktyki, ratyfikowany obecnie przez 59 państw, określił status prawny obszaru, kończąc w ten sposób roszczenia terytorialne wysuwane przez niektóre państwa. Wprowadza też znaczącą reglamentację aktywności ludzi w tym obszarze.

Zasady dotyczące ochrony środowiska, procedury oraz wynikające z nich obowiązki wprowadza Protokół o ochronie środowiska do Układu w sprawie Antarktyki (wraz z aneksami) sporządzony w Madrycie 4. października 1991 r. (dalej jako Protokół z 1991 r.). Na jego mocy obszar ustanowiono rezerwatem naturalnym, podlegającym kompleksowej ochronie.

W Protokole z 1991 r. i tworzących integralną część załącznikach, zostały ustanowione reguły ochrony rodzimych gatunków roślin i zwierząt, zakaz wprowadzania osobników nieurodzonych na tym obszarze (załącznik nr II), wprowadzono zakazy dotyczące zrzucania do wód oleju, szkodliwych płynów, śmieci, ścieków, czy nawet używania PCBs oraz pestycydów (załącznik nr III i IV).
Turystyka została wymieniona jako jedna $\mathrm{z}$ aktywności (obok badań naukowych i innych rządowych i pozarządowych aktywności) wymagająca przeprowadzenia procedur ocenowych. Zgodnie z przyjętą procedurą, określoną w załączniku nr I, przed rozpoczęciem realizacji konieczne jest zakwalifikowanie projektu do jednej z trzech kategorii odzwierciedlających stopnień oddziaływania na środowisko - mniejszy niż niewielki lub czasowy skutek (a), niewielki lub czasowy skutek (b) oraz większy niż niewielki lub czasowy skutek (c). Szczegółowo procedurę ocenową opisuje załącznik I do Protokołu. Przeprowadzenie oceny ma zapewnić, że planowane aktywności nie wyrządzą negatywnych skutków na obszarze objętym Układem.

Wymagania dotyczące respektowania ochrony obszaru Antarktyki zostały nałożone zarówno na organizatorów wycieczek, jak również na ich uczestników.

Szczegółowe obowiązki tych podmiotów zostały zawarte m.in. w przyjętej w dwa lata po Protokole Rekomendacji (Recommendation ATCM XVIII-1, Kyoto, 1994) opisującej szczegółowo ich obowiązki w dwóch oddzielnych dokumentach.

W myśl Przewodnika dla organizatorów i operatorów ruchu turystycznego i innych pozarządowych aktywności, na organizatorów i operatorów został nałożony obowiązek uprzedniego uzyskania zezwolenia. We wniosku o jego wydanie określa się m.in. daty planowanych wycieczek, dokładny opis aktywności, przewidywaną liczbę uczestników, rodzaj i wielkość statków wycieczkowych (samolotów), liczbę i kwalifikacje załogi.

Zgodnie z obowiązującym Przewodnikiem dla odwiedzających Antarktykę, turyści, obok typowych ograniczeń dotyczących zachowania respektującego środowisko oraz bezpieczeństwo gatunków zwierząt, niepłoszenie ich, nie mogą wprowadzać obcych gatunków zwierząt (w tym domowych) na teren objęty Układem w sprawie Antarktyki. Zabronione jest również zbieranie i zabieranie jakichkolwiek skał, kości, jaj i innych 
przedmiotów w charakterze pamiątek z wycieczki.

Zdaniem A.N. Wright, (Wright 2008: 69) słabością regulacji dotyczących ochrony przyjętej w Protokole z 1991 r. jest jego ograniczona egzekwowalność, wynikająca m.in. z braku wejścia w życie jego Załącznika VI regulującego kwestie odpowiedzialności za naruszenie postanowień Protokołu w kwestiach dotyczących środowiska (w tym dotyczące odpowiedzialności dotyczącej ruchu turystycznego). Świadczy to o bezradności systemu Układu w sprawie Antarktyki wobec silnego lobby turystycznego.

Ogólne regulacje prawa międzynarodowego regulujące kwestie ochrony wód to Konwencja Narodów Zjednoczonych o prawie morza z 1992 r., Międzynarodowa konwencja o zapobieganiu zanieczyszczeniu morza przez statki, znana jako MARPOL 73/78, Konwencja o zanieczyszczaniu mórz przez zatapianie odpadów i innych substancji (Konwencja londyńska z 1972 r.) $\mathrm{i}$ inne konwencje dotyczące zapobiegania zanieczyszczeniom mórz. Wśród różnych obowiązków, wynika z nich jeden zasadniczy - obowiązek państw do zapobiegania i zachowania środowiska morskiego przed zanieczyszczeniami. Ich zastosowanie do obszaru Antarktyki jest jednak ograniczone, w części, w jakiej wpisują się w zakres regulacji poszczególnych konwencji.

Jeśli chodzi o regulacje dotyczące turystyki w obszarze Antarktyki pochodzące z porządków prawnych poszczególnych państw, na pierwszy plan wysuwają się regulacje dotyczące praw i obowiązków poszczególnych statków wynikające z przynależności bandery. W tym kontekście problematyczne jest zjawisko znane jako „tania bandera”, czyli rejestrowanie statków pod banderą państwa niezwiązaną z armatorem. Przyczyny takiej praktyki są złożone i często składają się na nie kwestie ochrony statków w przypadku konfliktów zbrojnych, ale również atrakcyjne warunki podatkowe, niskie koszty pracy, niskie wymogi techniczne statków, zarówno prawne jak i faktyczne, niesformalizowany tryb rejestracji. Przekłada się to na gorszy stan techniczny jednostek, a w konsekwencji na częstsze uleganie wypadkom (Becker 1998: 634). Zdaniem I. Zovko więcej niż połowa statków turystycznych obszaru Antarktyki pływa pod tanią banderą (Zovko 2007: 193-194). Polityka państw prowadzących rejestry taniej bandery, liczących głównie na wpływy z tytułu rejestracji statków, nie sprzyja dyscyplinowaniu finansowemu zanieczyszczających statków, co oznacza brak chęci bądź nawet odpowiednich regulacji prawnych w tym zakresie (Schulkin 2002: $115)$.

Już przywołanie w sposób dość ogólny systemu ochrony prawnej obszaru Antarktyki, pomimo licznych regulacji pochodzących z wielu źródeł, wcale nie przekłada się wysoki stopień ochrony obszaru, a wręcz przeciwnie. Przyjęcie rozwiązania polegającego na precyzyjnych i egzekwowalnych regulacji w zakresie odpowiedzialności za naruszenie przepisów mających chronić środowisko wydaje się w tej sytuacji stanem nieosiągalnym w najbliższej perspektywie.

\section{Konwencja waszyngtońska}

Wpływ handlu dziką fauną i florą na ich dobrostan był rozpoznany od dawna. Negatywne oddziaływanie wzrastało wraz ze zwiększającą się eksploracją ludzi nowych obszarów, wolnych dotychczas od obecności ludzi. Początek ubiegłego wieku był takim okresem, w którym zaczęto dostrzegać skalę zagrożenia, a postępujący proces ginięcia kolejnych gatunków, tylko wzmacniał obawy (Hemmings 2002: 96).

Objęcie zakresem zainteresowania również ruchu turystycznego znajduje swój wymiar psychologiczny, pozwala bowiem uświadomić nie zawsze zaangażowanym w ochronę przyrody turystom, jaki negatywny wymiar może mieć pozornie banalne zachowanie polegające na zakupieniu na lokalnym targu w Brazylii piórka ary hiacyntowej (anodorhynchus hyacinthinus), czy w Indonezji kakadu molucka (cacatua moluccensis) i przywiezienie go do domu jako wspomnienia z wakacji. Dąży do przekonania, że gatunki zagrożone wyginięciem, jeżeli 
już mają być atrakcją turystyczną, powinny nią pozostać w miejscach naturalnego bytowania tych gatunków.

Przygotowanie i podpisanie Konwencji o międzynarodowym handlu dzikimi zwierzętami i roślinami gatunków zagrożonych wyginięciem sporządzonej w Waszyngtonie w 1973 r. (dalej jako CITES) miało dawać instrument poddający kontroli handel zagrażający bytowi gatunków, tak aby handel nie prowadził do ich wyginięcia. Konwencję ratyfikowały 183 strony, w tym największe kraje, sprawia, że jednakowy mechanizm ochronny powinien obowiązywać na prawie całej Ziemi, dając odpowiednią ochronę. Zbierane dane wskazują na bardzo liczne przypadki nielegalnego handlu gatunkami objętymi CITES. Często bardzo liberalne podejście władz państwowych do egzekwowania przepisów CITES staje na przeszkodzie jej skuteczności. Pomimo większych oczekiwań dotyczących efektywności, CITES stwarza ramy prawne pozwalające reagować w sytuacjach zagrożenia.

W preambule CITES zawarto odniesienie dotyczące wartości dzikiej fauny i flory z punktu widzenia estetyki, nauki, ekonomiki, ale też kultury i rekreacji.

CITES wprowadziła reglamentację handlu okazami gatunków wymienionych. Jej stopień został uzależniony od umieszczenia gatunku w jednym z trzech załączników (zał. I - gatunki zagrożone wyginięciem; zał. II - gatunki, których objęcie reglamentacją handlu jest konieczne ze względów prewencyjnych - aby zapobiec nadmiernej eksploatacji, bądź poddania skutecznej kontroli; zał. III - objęte reglamentacją ze względu na stanowisko jednej ze stron Konwencji). Przypisanie gatunków do konkretnych załączników może podlegać zmianom, w zależności od ich aktualnego statusu. Największy stopień reglamentacji dotyczy gatunków wymienionych w załączniku I. Wydanie zezwolenia na handel, w ich przypadku, powinno być uzasadnione szczególnymi okolicznościami.

Co do zasady istotą reglamentacji jest obowiązek uzyskania zezwolenia na nabycie, przewiezienie przez granicę gatunków objętych CITES (z zastrzeżeniami zawartymi w art. VII tej Konwencji).

CITES poddaje reglamentacji handel okazami dzikich roślin i zwierząt. Pojęcie to należy rozumieć w znacznie szerszym znaczeniu niż obrót komercyjny. Nie chodzi bowiem tylko o sprzedaż okazów (żywych, martwych, fragmentów, takich jak pióra ptaków, kość słoniowa, zasuszone kawałki roślin, nasiona itp.) w celu uzyskania zysku, ale również ich niekomercyjny przewóz przez granicę. Motywacja dotycząca handlu jest bez znaczenia. Objete CITES jest zarówno nabycie przez organizację międzynarodową zajmującą się działalnością komercyjna, przewóz dla ogródu botanicznego (zoologicznego), jak również nabycie przez osoby prywatne, jeżeli łączy się z przekroczeniem granicy (Favre 1989: 25). Ograniczenia wynikające z CITES dotyczą zatem bezpośrednio turystów, którzy zwiedzając egzotyczne miejsca zapragną przywieść z nich pamiątki, wśród których będą okazy podlegające obowiązkowi przedniego uzyskania zezwolenia ze względu na CITES.

Ze względu na fakt, że najczęściej ruch turystyczny do egzotycznych miejsc odbywa się na pośrednictwem organizacji turystycznych, profesjonalnych podmiotów zajmujących się kompleksową obsługą turystów, w tym szczegółową organizacją pobytu na miejscu, podczas konferencji z okazji roku turystyki, która odbyła się w Genewie w kwietniu 2017 r., została zwrócona uwaga na szczególną rolę, jaką powinny odgrywać organizacje turystyczne w zachowaniu dzikich gatunków roślin i zwierząt. Sekretarz Generalny CITES zwrócił uwagę na działania, w jakie organizacje turystyczne moga włączyć się. Przede wszystkim wezwał do aktywnego promowania turystyki do miejsc egzotycznych opartej o świadome zachowanie kładące nacisk na zbieranie doświadczeń związanych z pobytem, a nie na negatywne oddziaływanie na miejsca odwiedzane. Podkreślił, jak duże znaczenie ma współpraca organizatorów wycieczek turystycznych z miejscowymi organami zajmującymi się 
ochroną dzikiej przyrody, w tym CITES i powiadamianie ich o zauważonych nielegalnych zachowaniach. Ponadto konieczne jest wzmocnienie świadomości kadry obsługującej ruch turystyczny w zakresie gatunków zagrożonych wyginięciem i innych podlegających ochronie. Nie bez znaczenia pozostaje współpraca z lokalną społecznością, której najczęściej zależy na zachowaniu niezmienionych dotychczasowych warunków przyrodniczych (Scanlon 2017).

\section{Podsumowanie}

Zaprezentowane $\mathrm{w}$ artykule regulacje dotyczące turystyki na obszarach chronionych przyrodniczo, chociaż to tylko wybrane akty, składają się na złożoną strukturę aktów o różnej mocy prawnej. Strukturę uzupełniają, pozostające poza zakresem artykułu, regulacje prawa krajowego. Odpowiedź prawa międzynarodowego na potrzeby związane z ochroną przyrody w związku z turystyką jest znacząca. Nie chodzi tutaj jedynie o wymiar legislacyjny, ale również o rozpowszechnienie problemu, a przez to zwrócenie uwagi na jego uniwersalny charakter, u podstaw którego można zidentyfikować destrukcyjny stosunek człowieka do natury (Sadowski 2017: 43).

Nie mniej jednak, konieczne jest podkreślenie, co wielokrotnie podnosi się w doktrynie, że najlepszym obrońcą lokalnej przyrody są jej mieszkańcy. Stąd wprowadzając różne regulacje związane z pobytem turystów, konieczne jest wzmacnianie warunków życia osób miejscowych, tak aby również oni stawali się bezpośrednimi beneficjentami rozwoju turystyki. Odpowiedzią na te postulaty jest koncepcja zrównoważonej turystyki, kładącej nacisk nie tylko na ochronę środowiska, lecz również udział społeczności lokalnej jako jej beneficjentów.

\section{Bibliografia}

Becker R., 1998, MARPOL 73/78: an overview in international Environmental enforcement, The Gerogetown International Environmental Law Review, vol. 10, 625-642.

Eagles P.F.J., McCool S.F., Haynes Ch.D., Philips A., 2002, Sustainable tourism in protected areas. Guidelines for planning and management, wyd. IUNC - The World Conservation Union.

Favre D.S., 1989, International Trade in Endangered Species, A Guide to CITES, wyd. Martinus Nijhoff Publishers, Dordrecht.

Gillespie A., 2007, Protected Areas and International Environmental Law, wyd. Martinus Nijhoff Publishers Leiden.

Hemmings J., 2002, Does CITES conserve biodiversity, Asia Pacific Journal of Environmental Law, Vol. 7, 95-124.

May D. S., 1999, Tourism and the environment, Natural Resources \& Environment, Vol. 14, 55-61.

Perez-Salom J-R., 2001, Sustainable tourism: emerging global and regional regulation, The Georgetow International Environemntal Law Review; vol. 13, 801-836.

Rada Europy, 1995, Commision of Minister Recommendation No R(95) 10 On a Sustaiable Tourist Development Policy in Protected Areas, 53rd Meeting od Ministers' Deputies

Sadowski R.F., 2017, Call for Integral Protection of Biocultural Diversity, Problems of Sustainable Development, Vol. 12, nr 2, 37-45.

Scanlon J.E., CITES calls on tourism and travel sector to join the fight against illegal wildlife trade, Press release, www.cites.org

Schulkin A., 2002, Safe harbours: crafting an itnernational solution to cruise ship pollution, The Gerogetown International Environmental Law Review, Vol. 15, 105-132.

Wright Asia N., 2008, Southern Exposure: Managing Sustainable Cruise Ship Tourism in Antarctica, California Western International Law Journal, Vol. 39, 43-86.

Zovko I., 2007, Vessel-sourced pollution in the Southern Ocean: benefits and shortcomings of regional regulation, w: Triggs G., Riddell A. Antarctica (eds.) „Legal and Environmental challenges for the future", wyd. British Institute of International and Comparative Law, 191-197. 


\title{
Tourism and protected areas from the perspective of the international environmental protection convention
}

\begin{abstract}
The article presents selected issues concerning tourist activity in protected areas because of natural values. The issues were presented in light of selected documents of international environmental law, which show great interest on the part of international law in the preparation of guidelines and best practices in order to raise awareness of the importance of tourist management for the proper protection of such areas. Sustainable tourism is argued to be the answer to the identified problems.
\end{abstract}

\section{Keywords}

tourism, international environmental protection, sustainable tourism 